\title{
Efektivitas Teknik Biofiltrasi Dengan Media Sarang Tawon Terhadap Penurunan Kadar Nitrogen Total Limbah Cair
}

\author{
Gea Paramudhita Sali ${ }^{1}$, Anggi Suprabawati ${ }^{1}$, Yuli Purwanto ${ }^{2}$ \\ 1) Departemen Kimia, Fakultas MIPA, Universitas Jenderal Achmad Yani, JI. Terusan Jendral \\ Sudirman, PO Box 148 Cimahi, Jawa barat \\ 2) Divisi Pengujian, PT Superintending Company of Indonesia, JI. Soekarno Hatta No 217, \\ Bandung 40233 \\ E-mail : geaparamudhitas@gmail.com
}

\begin{abstract}
Abstrak
Setiap limbah cair industri memiliki baku mutu yang dipersyaratkan berdasarkan PERMEN LH No. 5 Tahun 2014 Lampiran XLVII, sehingga dilakukanlah penelitian dalam upaya memperoleh suatu sistem pengolahan air limbah yang cukup sederhana untuk memenuhi baku mutu yang telah ditetapkan tersebut. Penelitian dilaksanakan dengan melakukan pengolahan limbah yang mengandung nitrat $\left(\mathrm{NO}_{3}\right)$, nitrit $\left(\mathrm{NO}_{2}\right)$, dan ammonia $\left(\mathrm{NH}_{3}\right)$ dengan menerapkan sistem nitrifikasi biologis yang menggunakan reaktor biofilter tercelup menggunakan media sarang tawon. Pemilihan sistem ini karena telah diketahui cara biologis adalah cara yang paling ekonomis dan reaktor biofilter tercelup merupakan sistem yang mudah dioperasikan dengan hasil yang cukup maksimal. Hasil penelitian diperoleh efektivitas penurunan kadar nitrit $\left(\mathrm{NO}_{2}\right)$ sebesar 97,23\%, kadar ammonia $\left(\mathrm{NH}_{3}\right)$ sebesar $85,80 \%$, kadar $\mathrm{N}$-total sebesar $43,65 \%$ dan kenaikan kadar nitrat $\left(\mathrm{NO}_{3}\right)$ sebesar $21,92 \%$, dengan waktu tinggal optimal selama 6-7 hari. Hal ini terjadi karena adanya bakteri pengurai yang melekat pada media sarang tawon yang dapat merombak senyawa-senyawa nitrogen.
\end{abstract}

Kata kunci : nitrifikasi, biofilter, media sarang tawon, bakteri nitrifikasi, nitrogen, limbah cair

\begin{abstract}
Based rules on PERMEN LH Regulation no. 5 of 2014 in XLVII that any industrial liquid waste must be required quality standards, so the research done for get a simple wastewater treatment system that can be applied in small industries. The research was carried out by processing nitrate $\left(\mathrm{NO}_{3}\right)$, nitrite $\left(\mathrm{NO}_{2}\right)$, and ammonia $\left(\mathrm{NH}_{3}\right)$ wastes by applying a biological nitrification system using an immersed biofilter reactor with a honeycomb medium. This biological system is the most economical way and easy to operate with maximum results. The result of the experiment showed that the decrease of nitrite $\left(\mathrm{NO}_{2}\right)$ level was $97,23 \%$, the ammonia $\left(\mathrm{NH}_{3}\right)$ was $85,80 \%$, the nitrogen total was $43,65 \%$ and the nitrate $\left(\mathrm{NO}_{3}\right)$ increase was $21,92 \%$ with optimal time of 6-7 days. This occurs because of the decomposing bacteria attached to the honeycomb medium which can break down the nitrogen compounds.
\end{abstract}

Keywords : nitrification, biofilter, honeycomb media, nitrifier bacteria, nitrogen, wastewater

\section{PENDAHULUAN}

Air limbah industri adalah sisa dari hasil produksi industri. Kualitas air limbah sangat bergantung pada tipe, jenis aktivitas, dan besar kecilnya industri.

Air limbah industri pada umumnya berasal dari :

1. Air limbah yang berasal dari proses produksi. Banyaknya limbah dan kualitas air limbah ini bergantung pada jenis produk yang dihasilkan industri. Biasanya banyak mengandung zat warna, senyawa- senyawa organik terlarut, dan mikroba.

2. Air pencuci alat-alat, mesin, wadah dan lain. Biasanya banyak mengandung detergen, antiseptik, dan materi terdispersi, serta mengandung sedikit produk yang dihasilkan oleh industri tersebut.

3. Air yang berasal dari pemanas atau pendingin. Air limbah ini dikenal dengan istilah pencemaran termik, karena air limbah ini mempunyai suhu yang tinggi.

4. Air yang berasal dari laboratorium pengawasan kualitas. Air limbah ini mengandung banyak senyawa kimia yang sering digunakan dalam proses pengujian seperti, asam, basa, garam, logam, dan senyawa organik.

Air buangan industri maupun air buangan domestik pada umumnya mengandung ion organik dan anorganik. Nitrat $\left(\mathrm{NO}_{3}\right)$, Nitrit $\left(\mathrm{NO}_{2}\right)$, dan Ammonia $\left(\mathrm{NH}_{3}\right)$ merupakan bagian dari siklus nitrogen yang bersifat karsinogenik. Baku mutu air 
limbah industri hasil produksi maupun laboratorium pengawasan kualitas berdasarkan PERMEN LH No. 5 Tahun 2014 Lampiran XLVII, konsentrasi nitrogen total maksimum pada lingkungan yang diperbolehkan adalah $30 \mathrm{mg} / \mathrm{L}$ dan ambang batas senyawa nitrat yaitu $20 \mathrm{mg} / \mathrm{L}$, nitrit dan ammonia yaitu $1 \mathrm{mg} / \mathrm{L}$.

Proses pengolahan air limbah secara biologi yang banyak digunakan adalah dengan biakan melekat. Proses yang sering digunakan yaitu teknik biofilter baik secara aerob maupun anaerob. Proses biofilter adalah teknik reaktor biologis dimana mikroorganisme tumbuh dan berkembang menempel pada permukaan media. Dengan adanya lapisan mikroorganisme yang tumbuh menempel pada permukaan media tersebut maka polutan yang ada di dalam air limbah akan diuraikan menjadi produk respirasi yaitu $\mathrm{CO}_{2}$ dan $\mathrm{H}_{2} \mathrm{O}$ (Marsidi dan Herlambang, 2002).

\section{Siklus Nitrogen}

Ammonia sangat berguna bagi tumbuhan dan mikroorganisme untuk asimilasi menjadi sel baru yang memberikan lebih banyak nitrogen organik. Untuk mengetahui sejauh mana peran senyawa nitrogen dalam proses pertumbuhan, maka perlu diketahui bentuk serta perubahannya yang terjadi di alam dalam suatu siklus yang disebut siklus nitrogen. Siklus nitrogen yang terjadi di lingkungan perairan, secara sederhana dapat diilustrasikan seperti pada Gambar 1.

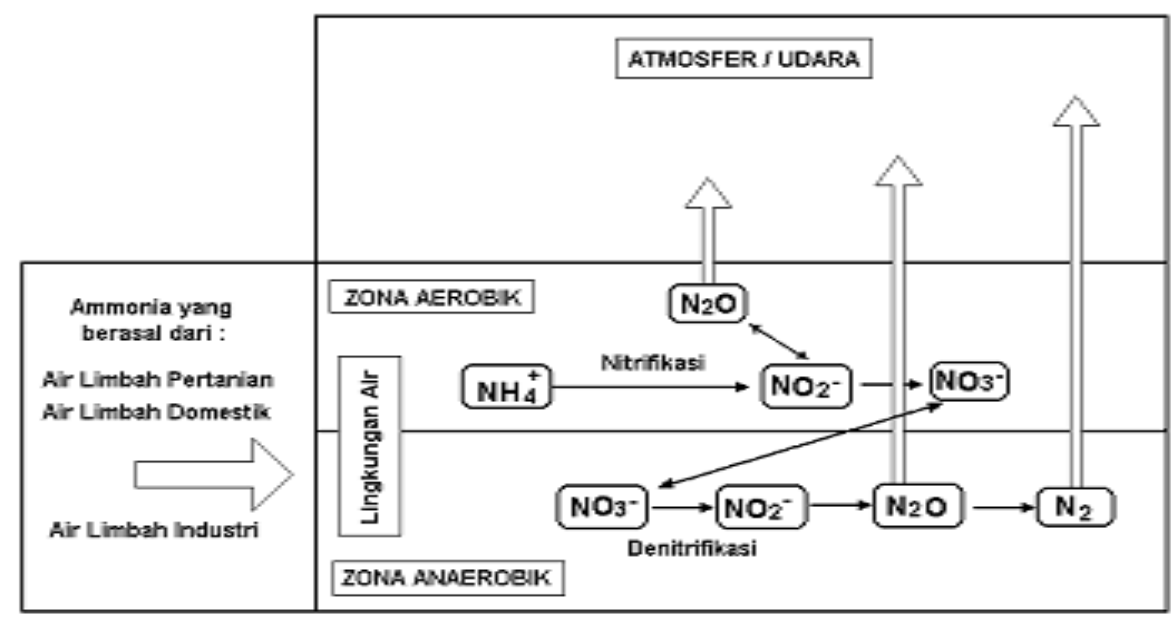

Gambar 1. Ilustrasi Siklus Nitrogen yang Terjadi di Lingkungan Perairan (Gabriel, 1994)

Senyawa nitrit merupakan bahan peralihan yang terjadi pada siklus biologi. Senyawa ini dihasilkan dari suatu proses oksidasi biokimia amonium, tetapi sifatnya tidak stabil karena pada kondisi aerobik, selama nitrit terbentuk, dengan cepat nitrit dioksidasi menjadi nitrat oleh bakteri nitrobacter. Sedangkan pada kondisi anaerobik, nitrat dapat direduksi menjadi nitrit yang selanjutnya hasil reduksi tersebut dilepaskan sebagai gas nitrogen. (Marsidi dan Herlambang, 2002).

\section{Proses Nitrifikasi}

Proses nitrifikasi didefinisikan sebagai konversi nitrogen ammonium $\left(\mathrm{N}-\mathrm{NH}_{4}\right)$ menjadi nitrit $\left(\mathrm{N}-\mathrm{NO}_{2}\right)$ yang kemudian menjadi nitrat $\left(\mathrm{N}-\mathrm{NO}_{3}\right)$ yang dilakukan oleh bakteri autotropik dan heterotropik (Gardy and Lim, 1980). Proses nitrifikasi melalui beberapa tahap yakni :
1. Tahap Nitritasi

Tahap ini merupakan tahap oksidasi ion amonium $\left(\mathrm{NH}_{4}{ }^{+}\right)$menjadi ion nitrit $\left(\mathrm{NO}_{2}{ }^{-}\right)$ yang dilaksanakan oleh bakteri nitrosomonas menurut reaksi berikut:

$$
\mathrm{NH}_{4}^{+}+1 / 2 \mathrm{O}_{2}+\mathrm{OH}^{-} \rightarrow \mathrm{NO}_{2}^{-}+\mathrm{H}^{+}+2 \mathrm{H}_{2} \mathrm{O}
$$

\section{Tahap Nitrasi}

Tahap ini merupakan tahap oksidasi ion nitrit menjadi ion nitrat $\left(\mathrm{NO}_{3}{ }^{-}\right)$yang dilaksanakan oleh bakteri nitrobacter menurut reaksi berikut :

$$
\mathrm{NO}_{2}^{-}+1 / 2 \mathrm{O}_{2} \rightarrow \mathrm{NO}_{3}^{-}
$$

Secara keseluruhan proses nitrifikasi dapat dilihat dari persamaan berikut :

$$
\mathrm{NH}_{4}^{+}+2 \mathrm{O}_{2} \rightarrow \mathrm{NO}_{3}^{-}+2 \mathrm{H}^{+} \mathrm{H}_{2} \mathrm{O}
$$

Kedua reaksi di atas berlangsung secara reaksi eksotermik (reaksi yang 
menghasilkan energi). Jika kedua jenis bakteri tersebut ada, baik di tanah maupun di perairan, maka konsentrasi nitrit akan menjadi berkurang karena nitrit yang dibentuk oleh bakteri nitrosomonas akan dioksidasi oleh bakteri nitrobacter menjadi nitrat.

\section{Media Biofilter Sarang Tawon}

Media sarang tawon merupakan media terstruktur dari bahan plastik dengan luas permukaan spesifik yang besar dan volume rongga yang besar sehingga dapat melekatkan mikroorganisme dalam jumlah yang besar dengan resiko kebuntuan yang sangat kecil.

Konstruksi media terstruktur biasanya merupakan lembaran dari bahan PVC (polyvinyl chlorida). Metoda konstruksi ini memungkinkan media terstruktur diproduksi dengan harga yang lebih murah per unit luas permukaan dibandingkan pencetakan secara injeksi. PVC relatif merupakan resin murah dengan sifat mekanik yang lebih baik dibandingkan PP atau HDPE. PVC pada awalnya bersifat hidrophobic namun biasanya menjadi basah atau mempunyai sifat kebasahan yang baik dalam waktu satu sampai dua minggu. Contoh media biofilter sarang tawon dapat dilihat pada Gambar 2.
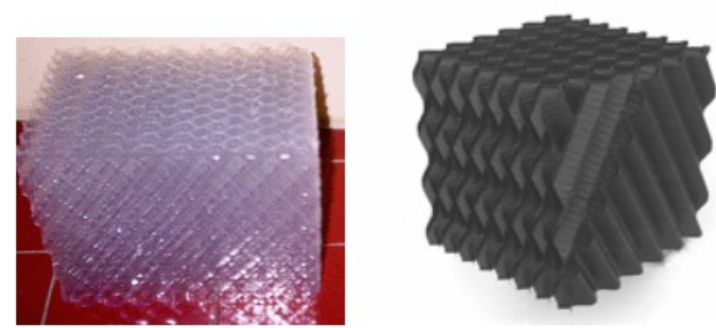

Gambar 2. Bentuk Media Terstruktur Tipe Sarang Tawon

Lembaran-lembaran PVC disambung membentuk blok segi-empat. Beberapa media mempunyai tube/ saluran dalam yang hanya mengalirkan sepanjang satu axis. Jenis lain dari media terstruktur yang dikenal sebagai cross corrugated packing yang memungkinkan aliran mengalir sepanjang dua axis. Hampir semua media terstruktur digunakan untuk biofilter adalah jenis aliran silang atau cross crosflow (Said dan Ruliasih, 2005).

Dengan mempertimbangkan beberapa aspek penting terhadap pemilihan media seperti luas permukaan spesifik, jenis material, perawatan, dan lainnya maka dilakukan penelitian untuk mengurangi konsentrasi nitrogen total ini salah satu nya dengan mencoba menggunakan teknik biofilter dengan media sarang tawon pada proses pengolahannya.

\section{METODOLOGI PENELITIAN}

Struktur reaktor biofilter menyerupai saringan (filter) yang terdiri atas media penyangga yang disusun baik secara teratur maupun acak di dalam suatu bejana. Fungsi media penyangga adalah sebagai tempat tumbuh dan berkembangnya mikroorganisme yang akan melapisi permukaan media membentuk lapisan massa yang tipis (biofilm). Mikroorganisme ini menguraikan bahan organik yang ada dalam air. Ketebalan lapisan biofilm menyebabkan difusi oksigen berkurang terhadap lapisan terdalam biofilm tersebut sehingga dapat menyebabkan terjadinya kondisi anaerobik pada lapisan permukaan media (Metcalf \& Eddy, 1991). Alur penelitian diilustrasikan pada Gambar 3.

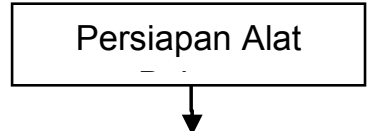

Pembuatan reaktor sederhana dengan sistem biofilter media sarang tawon

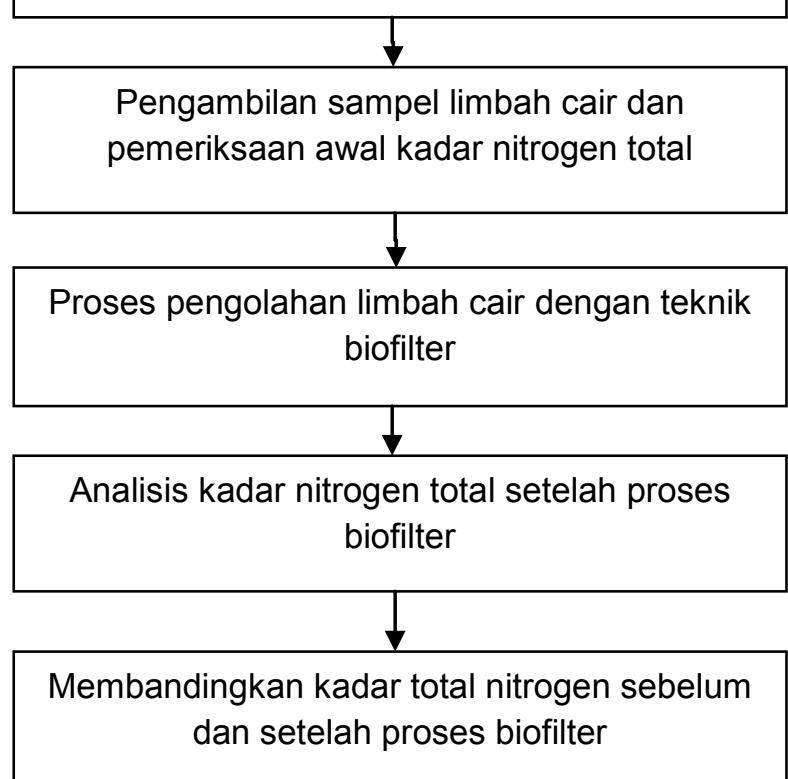

Gambar 3. Diagram Alir Penelitian

Penentuan Kadar Ammonia (SNI 066989.30-2005)

Alat dan Bahan yang digunakan yaitu Larutan fenol $\left(\mathrm{C}_{6} \mathrm{H}_{5} \mathrm{OH}\right) 40 \%$, Larutan Natrium Nitroprussid $\left(\mathrm{Na}_{2}\left[\mathrm{Fe}(\mathrm{CN})_{5} \mathrm{NO}\right]\right)$ $0.5 \%$, Larutan Oksidasi, dan Spektrofotometer UV-Vis. Penentuan kadar ammonia yaitu $25 \mathrm{~mL}$ sampel ditambahkan $1 \mathrm{~mL}$ Phenol dan $1 \mathrm{~mL}$ Nitroprussid, kemudian 2,5 mL larutan oksidasi. Intensitas dari warna biru yang dihasilkan diukur 
dengan menggunakan spektrofotometer pada panjang gelombang $640 \mathrm{~nm}$.

Penentuan Kadar Nitrit (SNI 06-6989.92004)

Alat dan Bahan yang digunakan yaitu larutan asam sulfanilat $1 \%$, larutan $\mathrm{N}$-(1naphthyl)-ethylenediamine (NED) $0.1 \%$ dan spektrofotometer UV-Vis. Analisa $\mathrm{NO}_{2}$ ini dilakukan secara kolorimetri dengan menambahkan $1 \mathrm{~mL}$ asam sulfanilat dan 1 $\mathrm{mL}$ larutan NED ke dalam $50 \mathrm{~mL}$ sampel Nitrit $\left(\mathrm{NO}_{2}\right)$ yang selanjutnya diukur absorbansinya pada panjang gelombang maksimum $539 \quad \mathrm{~nm}$ menggunakan spektrofotometer UV-Vis.

Penentuan Kadar Nitrat (APHA 4500- $\mathrm{NO}_{3}-\mathrm{B}$, 2012)

Alat dan Bahan yang digunakan yaitu $\mathrm{HCl} 1 \mathrm{~N}$ dan Spektrofotometer UV. Pada penentuan kadar nitrat $\left(\mathrm{NO}_{3}\right)$, sebanyak 50 $\mathrm{mL}$ sampel ditambahkan larutan $\mathrm{HCl} 1 \mathrm{~N}$. Kemudian diukur menggunakan spektrofotometer UV pada panjang gelombang $220 \mathrm{~nm}$.

\section{HASIL DAN PEMBAHASAN}

Sebelum proses biofilter berlangsung, sampel limbah dianalisa terlebih dahulu sebagai kontrol (pengukuran sampel awal) untuk melihat efisiensi maksimum dari proses biofilter media sarang tawon. Setelah proses biofilter dan pembiakan bakteri berjalan selama 3 (tiga) hari baru dilakukan analisa air sesudah pengolahan dengan masa tinggal sampai 7 hari. Analisa yang dilakukan meliputi Nitrat $\left(\mathrm{NO}_{3}\right)$, Nitrit $\left(\mathrm{NO}_{2}\right)$, dan Ammonia $\left(\mathrm{NH}_{3}\right)$.

\section{Penentuan kadar Ammonia}

Penurunan kadar ammonia setelah proses biofiltrasi terjadi secara signifikan pada hari ke 7 yaitu sebesar $85,80 \%$ dibandingkan dengan kontrol (pengukuran sampel awal). Dapat dilihat pada Gambar 4.

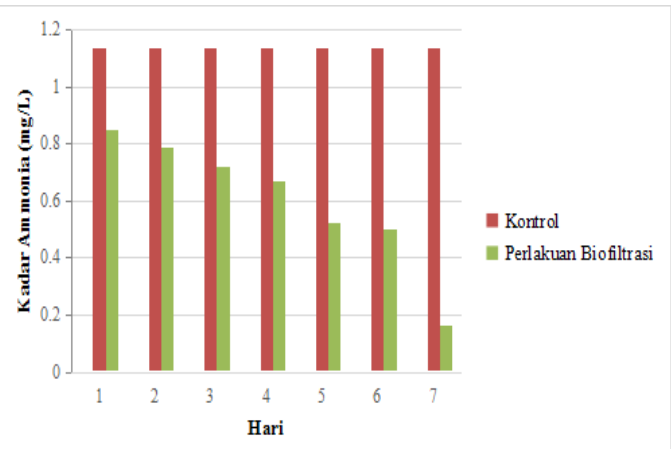

Gambar 4. Konsentrasi Ammonia
Penurunan kadar ammonia ini berbeda dengan kadar nitrit dimana kadar ammonia ini terjadi penurunan siginifikan pada hari ke 7. Perbedaan tersebut dapat diakibatkan karena bakteri pengurai ammonia yaitu Nitrosomonas mengalami fase exponensial atau fase pertumbuhan yang optimal pada hari ke 7 setelah proses seeding (pembiakan bakteri). Dapat dilihat pada Gambar 5.

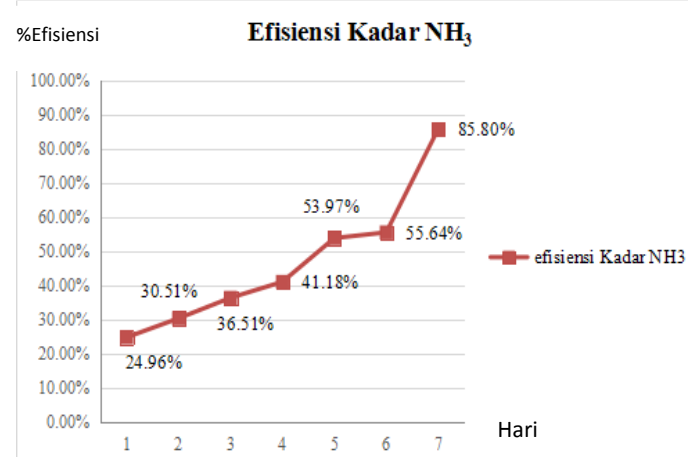

Gambar 5. Efisiensi Penurunan Kadar Ammonia

\section{Penentuan kadar Nitrit}

Penurunan kadar nitrit setelah proses biofiltrasi terjadi secara signifikan pada hari ke 6 yaitu sebesar 97,23\% dibandingkan dengan kontrol (pengukuran sampel awal). Dapat dilihat pada Gambar 6 dan Gambar 7. Nitrit merupakan senyawa beracun dimana penurunan kadar nitrit ini sudah mencapai kadar yang aman untuk lingkungan.

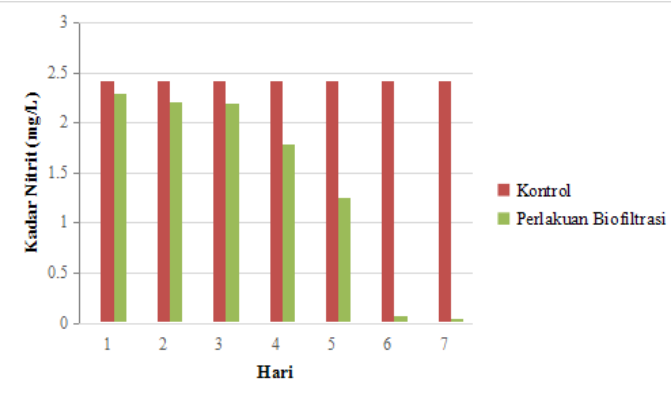

Gambar 6. Konsentrasi Nitrit

Penurunan kadar nitrit ini disebabkan karena adanya proses nitrifikasi. Proses nitrifikasi dapat ditulis dengan reaksi berikut ini :

$$
\begin{gathered}
\mathrm{NH}_{3}+\text { oksigen }+\begin{array}{c}
\text { Nitrosomonas } \\
\text { energi }
\end{array} \\
\mathrm{NO}_{2}^{-}+ \\
\mathrm{NO}_{2}^{-}+\text {oksigen }+ \\
\text { energi } \\
\text { entebacter } \rightarrow \mathrm{NO}_{3}^{-}{ }^{-}
\end{gathered}
$$




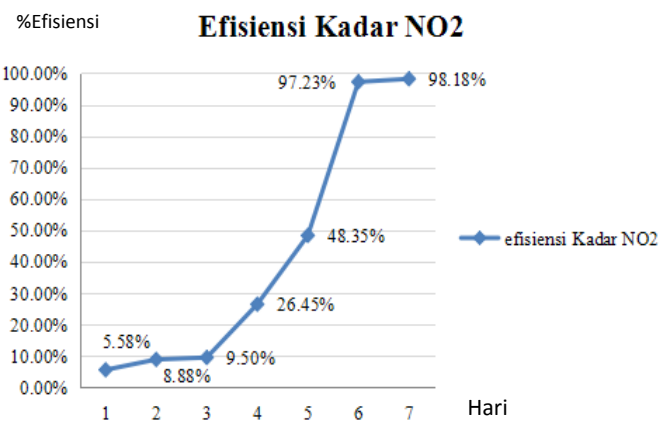

Gambar 7. Efisiensi Penurunan Kadar Nitrit

Penentuan kadar Nitrat

Kadar nitrat setelah proses biofiltrasi mengalami kenaikan tertinggi sebesar $21,92 \%$ dibandingkan kontrol (pengukuran sampel awal) pada hari ke 6. Dapat dilihat pada Gambar 8 dan Gambar 9.

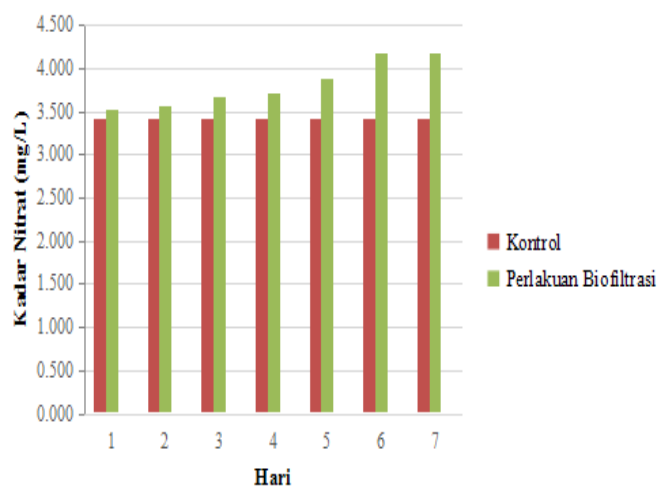

Gambar 8. Konsentrasi Nitrat

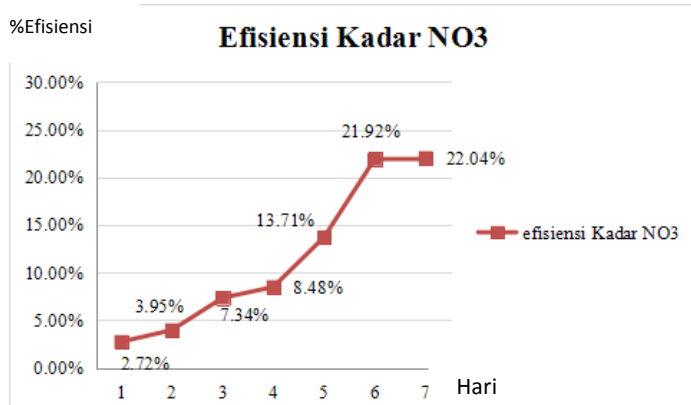

Gambar 9. Efisiensi Penurunan Kadar Nitrat

Keberadaan nitrat diperairan umumnya stabil. Kenaikan kandungan nitrat setelah melalui proses biofiltrasi dapat disebabkan karena kondisi biofilter aerobik, bukan anaerob. Sehingga pada saat terjadi nitrifikasi ammonia berubah menjadi nitrit kemudian menjadi nitrat yang akhirnya menambah konsentrasi nitrat.

\section{Penentuan kadar Nitrogen Total}

Kandungan total nitorgen yang di analisa pada air limbah laboratorium ini merupakan nitrogen anorganik yang meliputi $\mathrm{N}$ - ammonia, N-nitrat dan N-nitrit. Untuk perhitungan kandungan total nitrogen ini didasarkan pada perbandingan konsentrasi ammonia, nitrat dan nitrit terhadap massa molekul relatifnya masingmasing.Penurunan kadar $\mathrm{N}$-total setelah proses biofiltrasi terjadi secara signifikan pada hari ke 6 yaitu sebesar 43,65\% dibandingkan dengan kontrol (pengukuran sampel awal). Dapat dilihat pada Gambar 10 dan Gambar 11.

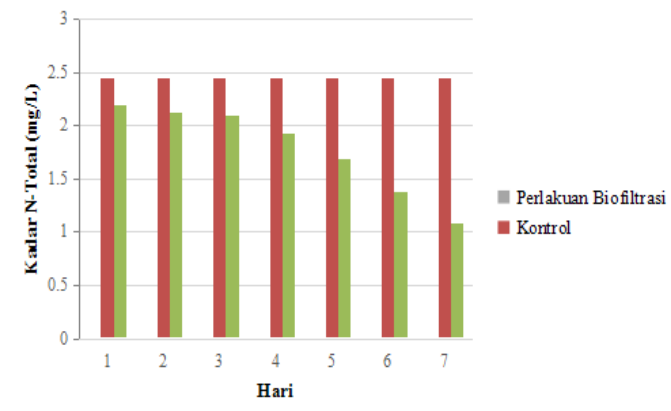

Gambar 10. Konsentrasi Total Nitrogen

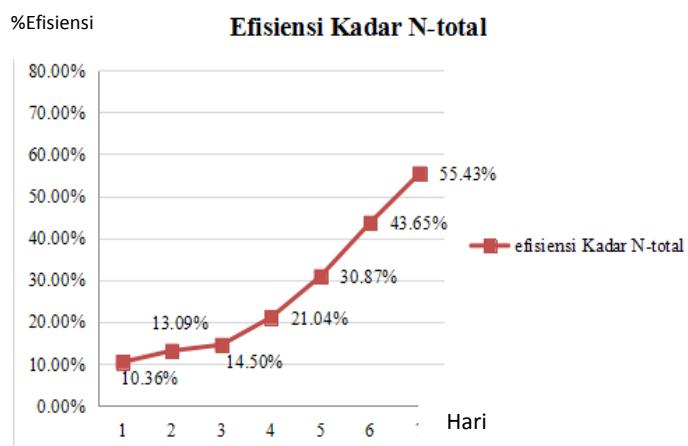

Gambar 11. Efisiensi penurunan kadar nitrogen total

\section{Pembentukan Biofilm}

Proses pembentukan biofilm setelah proses pembiakan bakteri yang dilakukan selama 3 hari tidak dapat terlihat secara jelas karena warna dan kekeruhan dari limbah yang digunakan cukup pekat. Namun setelah masa tinggal 7 hari, saat media diangkat dari reaktor, permukaan media sedikit berlendir dimana lapisan lendir tersebut sangat tipis berwarna bening.

Menurut teoritis biofilm terbentuk secara cepat dalam sistem yang mengalir dimana suplai nutrisi tersedia secara teratur bagi bakteri. Sehingga sangat penting untuk menyuplai nutrisi bakteri salah satunya dengan memperhatikan kondisi oksigen yang cukup serta $\mathrm{pH}$ dan temperatur yang sesuai dengan kondisi bakteri. Bakteri Nitrosomonas optimum pada $\mathrm{pH}$ 6,0-9,0 dan suhu antara $20^{\circ} \mathrm{C}$ sampai $30^{\circ} \mathrm{C}$. Sedangkan bakteri Nitrobacter akan tumbuh optimal pada suhu $28^{\circ} \mathrm{C}$ dan memiliki $\mathrm{pH}$ optimum 
antara 7,3 dan 7,5 serta akan mati pada suhu diatas $49^{\circ} \mathrm{C}$ atau di bawah $0^{\circ} \mathrm{C}$.

\section{KESIMPULAN}

Berdasarkan hasil penelitian, teknik biofiltrasi menggunakan media sarang tawon efektif menurunkan kadar nitrogen total dalam air limbah karena dapat memenuhi baku mutu air limbah yang dipersyaratkan.

\section{UCAPAN TERIMAKASIH}

Penulis mengucapkan terimakasaih kepada staf laboratorium PT. Sucofindo Cabang Bandung yang telah membantu dan memfasilitasi penelitian ini.

\section{DAFTAR PUSTAKA}

APHA. 2012. Official methods of Standard Methods for Examination of Water and Waste Water $22^{\text {nd }}$ Edition. APHAWashington.

Belser, L.W. 1979. Populationecology of nitrifying bacteria. Annual reviews in Microbiology. Vol 33 : 309-333.

Day and Underwood. 2002. Analisis Kimia Kuantitatif Ed. 6. Jakarta: Erlangga.

Gabriel, B. 1994. Wastewater Microbiology. New York: A John Wiley \& Sons, INC.

Gardy, C.P.L and Lim, H.C. 1980. Biological Waste Water Treatment Theory\&Application. New York : Mercell Dekker, Inc.

Hitdlebaugh, J.A dan R.D. Miller. 1981. Operational Problems With Rotating Biological Contractor. dalam Journal Water Pollution Control Fed : 53.

Horan, N.J. 1990. Biological Wastewater Treatment systems:Theory and Operation. University of Leeds, England. John Wiley \& Sons Ltd.

Khopkar, S. M. 2003.Konsep Dasar Kimia Analitik. Terjemahan Saptohardjo. UI Press : Jakarta.

Koestoer, Y. 1995. Kimia dan Ekotoksikologi Pencemaran, Terjemahan dari
Chemistry and Ecotoxicology ofPollution oleh D.W. Connel, UI Press : Jakarta.

Linsley, R. K. 1991. Teknik Sumber Daya Air Jilid II : Diterjemahkan Oleh Djoko Sasongko : Penerbit Erlangga.

Marsidi, R dan Herlambang, A. 2002. Proses Nitrifikasi dengan Sistem Biofilter Untuk Pengolahan Air Limbah yang Mengandung Amonia Konsentrasi Tinggi. dalam Jurnal Teknologi, Vol.3, No.3, September 2002 : 195-204.

Metcalf and Eddy. 1978. Waste Water Engineering. Mc Graw Hill.

Painter, H.A dan J.E. Loveless. 1981. Effect of Temperature and $\mathrm{pH}$ Value On The Growth Rate Contants of Nitrifying Bacteria in the Activated Sludge Process. (Water Research)

Peraturan Menteri Lingkungan Hidup No. 5 Tahun 2014 Lampiran XLVII tentang Baku Mutu Limbah Cair Bagi Kegiatan Industri di Jawa Barat.

Rachmawati. 2006. Kajian Aplikasi Bakteri Nitrosomonas sp. Pada Teknik Biofilter Untuk Penghilangan Emisi Gas Amoniak. Skripsi. IPB. Bogor.

Said, N. I dan Ruliasih. 2005. Tinjauan Aspek Teknis Pemilihan Media Biofilter Untuk Pengolahan Air Limbah. dalam Jurnal Teknologi Pengelolaan Air Bersih dan Limbah Cair, Pusat Pengkajian dan penerapan Teknologi Lingkungan, BPPT Vol.1, No.3.

Situmorang, M. 2007. Kimia Lingkungan, cetakan I. Medan: Fakultas MIPA UNIMED. Hal: 45,115.

Standar Nasional Indonesia (SNI).Jakarta : Badan Standarisasi Nasional

U.S. EPA. 1975. Process Design Manual for Nitrogen Control. Washington DC : Office of Technology Transfer.

Verstraete, W and Alexander, M. 1972. Heterotrophic nitrifiction by Arthrobacter sp. 110: 955. 